\title{
An Unexpected Image on Plain Radiograph in a Child with Abdominal Complaints: A Case Report
}

\author{
Abdominal Şikayetleri Olan Bir Çocukta Düz Radyografide Beklenmedik Görüntü: \\ Bir Olgu Sunumu
}

\author{
(D) Nilgün Erkek¹, (D) Latife Öz², (D) Meryem Keçeli Başaran33, (D) Gökhan Arslan4 \\ ${ }^{1}$ Akdeniz University Faculty of Medicine, Department of Pediatric Emergency, Antalya, Turkey \\ ${ }^{2}$ Akdeniz University Faculty of Medicine, Department of Child Health and Diseases, Antalya, Turkey \\ ${ }^{3}$ Akdeniz University Faculty of Medicine, Department of Pediatric Gastroenterology and Nutrition, Antalya, Turkey \\ ${ }^{4}$ Akdeniz University Faculty of Medicine, Department of Radiology, Antalya, Turkey
}

\section{Abstract}

Plain radiography is a useful tool for distinguishing many intraabdominal pathologies and it rarely leads to a surprising diagnosis. Here, present a 12-year-old girl who presented with abdominal discomfort, dull pain and tenderness on palpation in the right upper quadrant, epigastrium and the right flank. Plain radiography showed an opacification due to gastric wall thickening. She was diagnosed with gastric ulcer, erosive gastropathy and duodenal ulcer based on findings of endoscopic examination. Her NSAID medication was ceased, and she was commenced on proton pump inhibitor. Her symptoms and radiological and endoscopic findings improved after two months of treatment. Gastric wall thickening seen on plain radiography as an opacified area is a rare evidence of peptic ulcer in children and may guide to choose endoscopy first instead of other modalities involving exposure to ionising radiation in further evaluation.

Keywords: Gastric wall thickening, plain radiography, intra abdominal opacification, child, gastric ulcer

\section{Öz}

Düz radyografi birçok intraabdominal patolojiyi ayırt etmek için yararlı bir araçtır ve nadiren şaşırtıcı bir tanıya götürür. Burada sunulan 12 yaşındaki kız çocuğun abdominal rahatsızlığı, sağ üst kadran, epigastrium ve sağ böğürde künt bir ağrısı ve palpasyonla hassasiyeti vardı. Düz radyografi gastrik duvar kalınlaşmasına bağlı bir opaklaşmayı gösterdi. Endoskopik inceleme ile gastrik ülser, eroziv gastropati ve duodenal ülser tanısı konuldu. NSAID ilacı kesildi ve proton pompa inhibitörü başlandı. İki aylık tedavinin sonunda semptomları, radyolojik ve endoskopik bulguları geriledi. Opasifiye bir alan olarak düz radyografide görülen mide duvarı kalınlaşması, çocuklarda peptik ülser için nadir bir kanıttır ve ileri değerlendirmede radyasyon veren diğer modaliteler yerine, önce endoskopiyi seçmeye kılavuzluk edebilir.

Anahtar Kelimeler: Gastrik duvar kalınlaşması, düz radyografi, intraabdominal opasifikasyon, çocuk, gastrik ülser

\section{Introduction}

Radiological imaging among a variety of modalities is extremely valuable as a diagnostic tool in pediatrics. In children with abdominal complaints, plain abdominal radiography allows initial assessment of a group of medical or surgical conditions and diseases. ${ }^{1}$ Plain abdominal radiographs can provide information on structures according to changes in soft tissue, air and bony densities. In a prospective study including 354 children presenting with abdominal complaints who underwent plain abdominal radiography, Rothrock et al. ${ }^{2}$ reported that plain radiograph showed major diseases in $17 \%$ of patients. In a plain radiograph, findings might be suggestive of foreign body ingestion, pyloric stenosis, intussusception, ileus, obstruction, necrotizing enterocolitis, gastroenteritis, pathologic calcification, and masses, etc. They can be used to make definitive diagnosis or be a distinguishing tool to guide further investigations. ${ }^{1-4}$ 


\section{Case Report}

A 12-year-old girl presented with a history of nausea, vomiting, abdominal discomfort and pain for four days. Pain was of acute onset, located in the right upper quadrant and radiated to the back. Pain did not change with meal. She did not report blood or bile in vomit. She also stated that she had seasonal mild dyspeptic complaints for one year but without any medical evaluation. She has taken non-steroidal anti-inflammatory drugs (NSAID) orally 1-4 tablets per day for four days. In her medical history, it was found that she had asthma and has been on prophylactic inhaled budesonide for two years, and she was heterozygous for familial Mediterranean fever. She was living with her recently divorced single mother. Her mother had dyspeptic complaints with no definitive diagnosis and did not receive any treatment. On physical examination, she was well and cooperative. Her body temperature was $36.2^{\circ} \mathrm{C}$, heart rate $-84 / \mathrm{min}$, respiratory rate $-18 / \mathrm{min}$, arterial blood pressure $-123 / 74 \mathrm{mmHg}$, and $\mathrm{SPO}_{2}-99 \%$. She had a soft abdomen but a dull pain and tenderness in the right upper quadrant, epigastrium and right flank pain on palpation. Her complete blood count, electrolytes, blood biochemistry for liver enzymes and renal function tests, pancreatic amylase, lipase, urine analyses for microscopy and crystalluria, and urine culture were unremarkable. Plain radiography was performed to rule out renal or biliary pathologies such as calculi, and radiology consultion was obtained (Figure 1).

\section{What are the radiological findings and what is the likely diagnosis?}

\section{Discussion}

Plain radiography showed an irregularly circular opacified area in the left upper quadrant. There is a wide variety of calcifications seen on plain abdominal radiography. Calcifications can be categorized by organ system and location in the abdomen such as calculi of urinary tract, calcifications of digestive tract, liver and gall bladder, peritoneal and surrenal region calcifications, phleboliths, appendicoliths, vascular calcifications, etc. 5,6 Radiology department stated that there was an opaque area

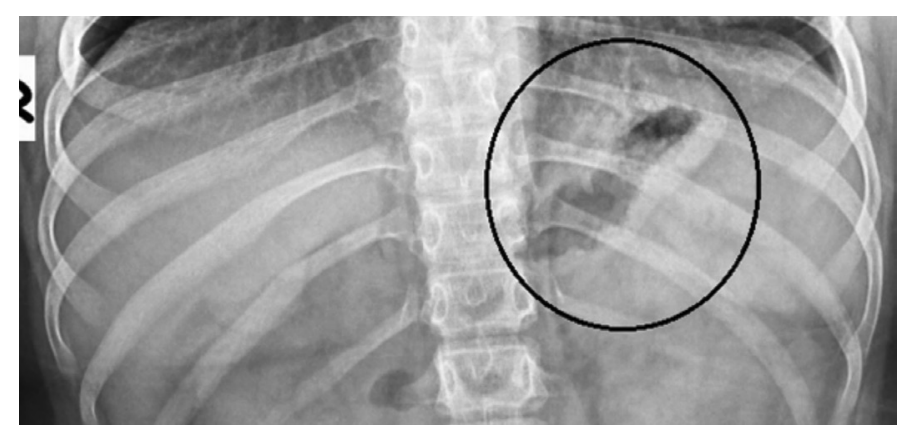

Figure 1. Abdominal plain radiography of the patient shows an opaque area related to gastric wall thickenning related to gastric wall thickening and no other abnormalities in plain radiography of the patient.

Gastric wall mucosa consists of two mucosal pattern; areae gastricae and gastric rugae. Gastric rugae are macromucosal folds of the mucosa and submucosa that tend to parallel to long axis of the stomach and are normally about 3-5 mm thick on computed tomography (CT) imaging and barium studies. Presence of abnormalities such as thicker and nodular rugal folds, appearing like gastric wall thickening, may signify additional pathological process. ${ }^{7,8}$ In the etiology of gastric wall thickening, there are various causes such as malignancies, infections, chronic inflammation, corrosive ingestion, radiotherapy, eosinophilic gastroenteritis, amyloidosis and, rarely, H. pylori gastritis. ${ }^{9,10}$ Several adult patients who received the diagnosis of gastrointestinal stromal tumor after an evaluation based on plain radiographs or CT findings showing spherical, solitary or punctate calcifications in the left upper quadrant with gastric wall thickening have been reported in the literature. ${ }^{11-13}$ However, we could not find any report emphasizing a gastric wall thickening seen on plain radiography as an opacified area in children with gastric ulcer. It is reasonable to advise that preferred imaging modality to depict the etiology of gastric wall thickening should be CT or double contrast examination of the upper gastrointestinal tract.9,10 However, our patient had a pain located in the right upper quadrant and radiating to her back side. To rule out other abdominal pathologies with similar symptoms such as renal calculi, cholelithiasis, mass or mesenteric lymphadenitis, an abdominal ultrasonography (US) was preferred in our patient which revealed no significant findings. Before ordering another imaging modality, pediatric gastroenterology consultation was obtained and then she underwent endoscopic examination demonstrating multiple lesions compatible with duodenal mucosal ulcer and hemorrhagic erosive gastritis and ulcer (Figure 2). Gastric and duodenal biopsies demonstrated mild grade duodenitis, erosive gastritis with negative $H$. Pylori result, and no atrophy or atypical figure. It has been reported in the literature that exaggerated gastric folds appearance might be related to an underlying mucosal inflammation with excessive production of acid, mucus and exudate.,14

Gastritis, gastric and duodenal ulcers occur infrequently in the pediatric population. Children present with a dull pain of hunger in epigastrium described as a gnawing or burning sensation, abdominal discomfort, fullness, nausea, vomiting, bloating. When aggressive factors overwhelm the natural mucosal protective barriers, gastritis and ulcers appear. Besides having intermittent dyspeptic complaints, the patient also had a recent history of NSAID and inhaled budesonid use, and possible separation anxiety of our patient might also have 


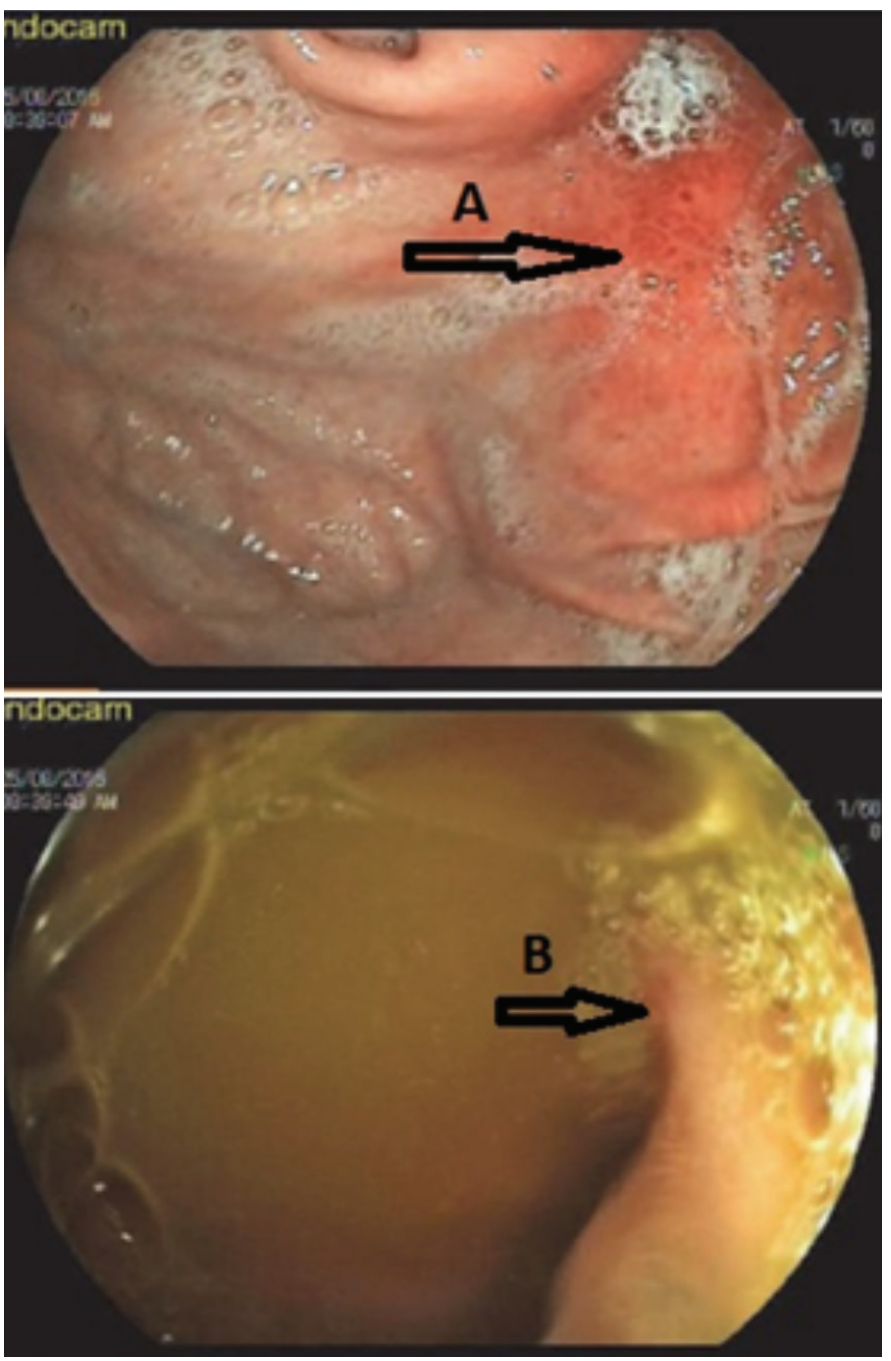

Figure 2. Endoscopic findings of the patient $A$ ) An erosive gastropathy area on fundus B) An $0.5 \mathrm{~cm}$ in diameter acut ulcer area on bulbus wall

been related to her gastric pathologies. ${ }^{15,16}$ Consequently, it can be said that factors mentioned above have detrimental effects resulting in inflammation and gastric epithelial and fibromuscular hyperplasia, vascular ectasia and edema, which may explain the reflection of opacified area related to gastric wall thickening on plain radiography.

We preferred plain radiography first to eliminate opaque and semiopaque gallstones and urinary stones. Other imaging modalities such as US or CT can visualize the location, origin and structure of the abdominal pathology. US was preferred because of cost effectiveness and to avoid side effects of radiation. ${ }^{17}$

As a good negative finding, we could not figure out gastric wall on US and also could eliminate cholelithiasis, nephrolihtiasis and intraabdominal mass with calcification as differentials. ${ }^{18}$ It was reasonable to give priority to endoscopic examination in our patient because her complaints pointed at gastric discomfort and also because endoscopy with biopsy is the gold standard to diagnose gastric mucosal pathologies if it is available. ${ }^{16,19}$

She was advised to discontinue NSAID, prescribed proton pump inhibitor and follow-up examination was arranged. 15,16,19 Her re-evaluation after two months of treatment revealed improvement in her complains and her radiological and endoscopic findings as shown in the literature. ${ }^{20}$

Gastric wall thickening seen as an opaque area on plain radiography is exceptional visual evidence in children and endoscopy may be considered first instead of the other modalities with radiation. To our knowledge, there have been no reports to explain such a radiological finding associated with a bundle of abdominal complaints and peptic disease in children. We also want to emphasize that when exploring varying causes of abdominal complains in a child, what the patient's history and physical examination are indicating, and what the benefit and harm of the preferred imaging modality are, should be considered.

\section{Significance of the Study}

To our knowledge, there have been no reports of such a finding in a pediatric patient, gastric wall thickening as an opacified area related with gastric ulcer seen on plain radiography. This is exceptional visual evidence and may lead to endoscopy first instead of the other techniques with radiation.

\section{Ethics}

Informed Consent: Informed consent was obtained from patient and parent.

Peer-review: Externally peer reviewed.

\section{Authorship Contributions}

Concept: N.E., L.Ö., M.K.B., G.A., Design: N.E., L.Ö., M.K.B., G.A., Data Collection or Processing: N.E., L.Ö., M.K.B., G.A., Analysis or Interpretation: N.E., L.Ö., M.K.B., G.A., Literature Search: N.E., L.Ö., M.K.B., G.A., Writing: N.E., L.Ö., M.K.B., G.A.

Conflict of Interest: No conflict of interest was declared by the authors.

Financial Disclosure: The authors declared that this study received no financial support.

\section{References}

1. Hee JL. Plain Abdominal Radiography in Infants and Children. Korean J Pediatr Gastroenterol Nutr. 2011;14:130-6.

2. Rothrock SG, Green SM, Harding M, Bervel D, Rush JJ, et al. Plain abdominal radiography in the detection of acute medical and surgical disease in children: a retrospective analysis. Pediatr Emerg Care. 1991;7:281-5. 
3. Barry J, Barry K.The Abdominal Radiograph. Ulster Med J. 2013;82:179-87.

4. Rothrock SG, Green SM, Hummel CB. Plain abdominal radiography in the detection of major disease in children: A prospective analysis. Ann Emerg Med. 1992;21:1423-9.

5. Bassano JM. Abdominal calcifications and diagnostic imaging decision making: a topic review. J Chiropr Med. 2006;5:43-52.

6. Chen MY, Bechtold RE, Bohrer SP, Zagoria RJ, Dyer RB. Abnormal calcification on plain radiographs of the abdomen. Crit Rev Diagn Imaging. 1999;40:63-202.

7. Press AJ. Practical significance of gastric rugal folds. Am J Roentgenol Radium Ther Nucl Med. 1975;125:172-83.

8. Pickhardt PJ, Asher DB. Wall Thickening of the Gastric Antrum as a Normal Finding: Multidetector CT with Cadaveric Comparison. AJR. 2003;181:973-9.

9. Rakita D, Hines JJ, Davidoff $S$, Sideridis K, Yacobozzi M, et al. CT imaging of endoscopy-confirmed gastric pathology. Applied Radiology Nov. 2013:18-26. https://www.appliedradiology.org/ acc. date: 08.02.2017

10. Horton KM, Fishman EK. Current Role of CT in Imaging of the Stomach. Radio Graphics. 2003;23:75-87.

11. Izawa N, SawadaT, Abiko R, Kumon D, Hirakawa M, et al. Gastrointestinal stromal tumor presenting with prominent calcification. World J Gastroenterol. 2012;18:5645-8.

12. Darnell A, Dalmau E, Pericay C, Musulén E, Martín J, et al. Gastrointestinal stromal tumors. Abdom Imaging. 2006;31:387-99.
13. Kim HC, Lee JM, Kim KW, Park SH, Kim SH, et al. Gastrointestinal stromal tumors of the stomach: CT findings and prediction of malignancy. AJR Am J Roentgenol. 2004;183:893-8.

14. Yasunaga $Y$, Shinomura $Y$, Kanayama S, Yabu M, Nakanishi T, et al. Improved fold width and increased acid secretion after eradication of the organism in Helicobacter pylori associated enlarged fold gastritis. Gut. 1994;35:1571-4.

15. Drumm B, Rhoads JM, Sringer DA, Sherman PM, Ellis LE, et al. Peptic ulcer disease in children etiology, clinical findings and clinical course. Pediatrics. 1988;82:410-4.

16. Malfertheiner P, Chan FK, McColl KE. Peptic ulcer disease. Lancet.2009;374:1449-61.

17. Thukral BB. Problems and preferences in pediatric imaging. Indian J Radiol Imaging. 2015;25:359-64.

18. Stringer DA, Daneman A, Brunelle F, Ward K, Martin DJ. Sonography of the Normal and Abnormal Stomach (Excluding Hypertrophic Pyloric Stenosis) in Children. J Ultrasound Med S. 1986:183-8.

19. Koletzko S, Jones NL, Goodman KJ, Gold B, Rowland M, et al. Evidence-based guidelines from ESPGHAN and NASPGHAN for Helicobacter pylori infection in children. H. pylori Working Groups of ESPGHAN and NASPGHAN. J Pediatr Gastroenterol Nutr. 2011;53:230-43.

20. Yasunaga Y, Shinomura Y, Kanayama S, Yabu M, Nakanishi T, et al. Improved fold width and increased acid secretion after eradication of the organism in Helicobacter pylori associated enlarged fold gastritis. Gut. 1994;35:1571-4. 